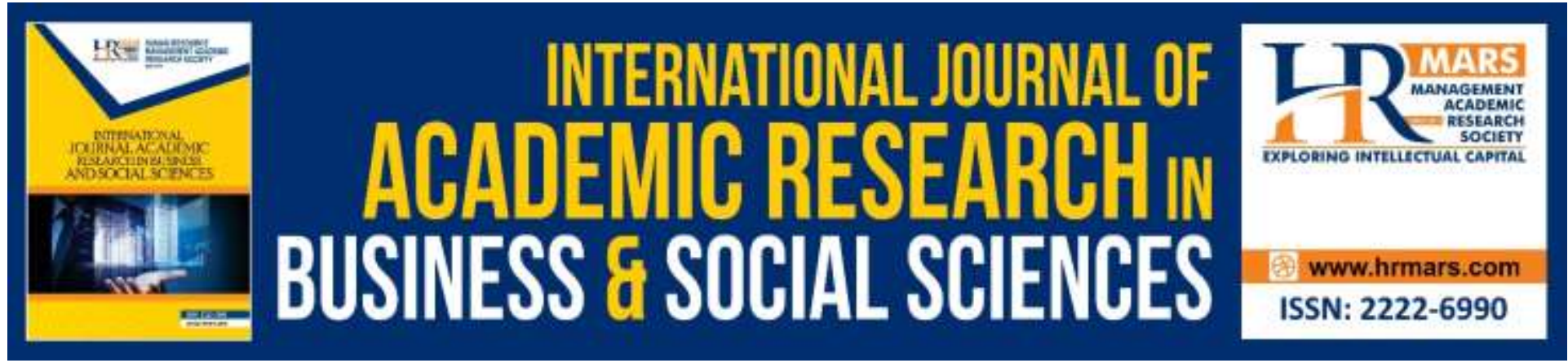

\title{
The Moderating Influence of Organization Culture in the Relationship between Workforce Diversity and Employee Performance in Public Universities in Western Kenya
}

Wycliffe Mande, Leon Awiti, Richard Misigo Imbambi, Ng'ong'a E. Aketch.

To Link this Article: http://dx.doi.org/10.6007/IJARBSS/v9-i9/6372

DOI: $10.6007 /$ IJARBSS/v9-i9/6372

Received: 15 July 2019, Revised: 10 August 2019, Accepted: 30 August 2019

Published Online: 24 September 2019

In-Text Citation: (Mande, Awiti, Imbambi, \& Aketch, 2019)

To Cite this Article: Mande, W., Awiti, L., Imbambi, R. M., \& Aketch, N. E. (2019). The Moderating Influence of Organization Culture in the Relationship between Workforce Diversity and Employee Performance in Public Universities in Western Kenya. International Journal of Academic Research in Business and Social Sciences, 9(9), 782-797.

Copyright: (c) 2019 The Author(s)

Published by Human Resource Management Academic Research Society (www.hrmars.com)

This article is published under the Creative Commons Attribution (CC BY 4.0) license. Anyone may reproduce, distribute, translate and create derivative works of this article (for both commercial and non-commercial purposes), subject to full attribution to the original publication and authors. The full terms of this license may be seen

at: http://creativecommons.org/licences/by/4.0/legalcode

Vol. 9, No. 9, 2019, Pg. 782 - 797

Full Terms \& Conditions of access and use can be found at http://hrmars.com/index.php/pages/detail/publication-ethics 


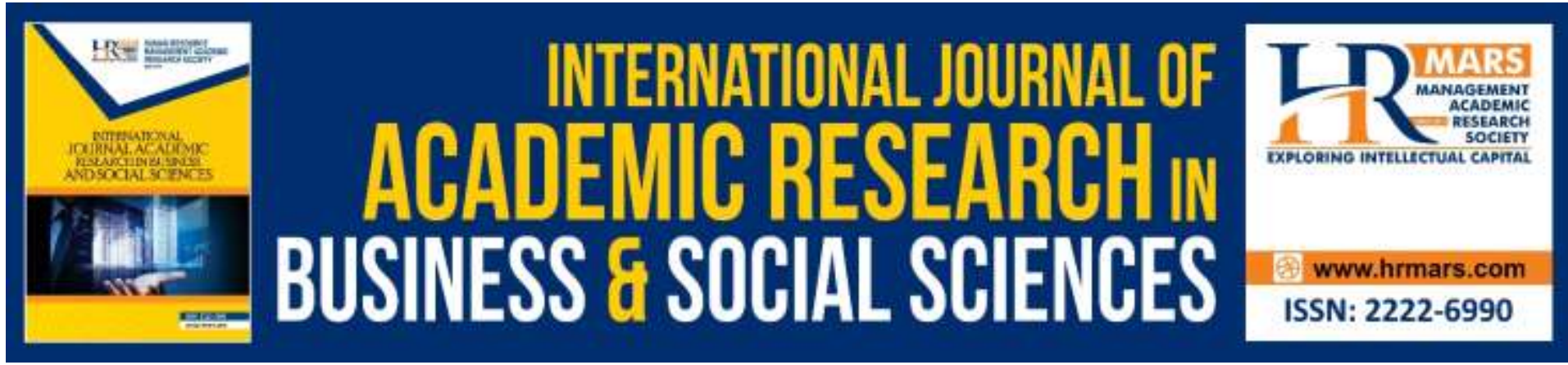

\title{
The Moderating Influence of Organization Culture in the Relationship between Workforce Diversity and Employee Performance in Public Universities in Western Kenya
}

\author{
Wycliffe Mande \\ Human Resource, Research and Learning Practitioner, Kenya. \\ Email: cliffmande@yahoo.com \\ Leon Awiti, Ph.D. \\ Monitoring, Evaluation, Research and Learning Practitioner, Kenya. \\ Email: awitileon@gmail.com \\ Richard Misigo Imbambi, Ph.D. \\ Email: rmimbambi@yahoo.com \\ Ng'ong'a E. Aketch, Ph.D. \\ Email: aketchngonga@yahoo.com
}

\begin{abstract}
The world's increasing globalization requires more interaction between people from diverse cultures and backgrounds than in the past. Considering that the world economy is now globalized and more culturally diverse, these multicultural work forces are making work environment different from traditional one. The objective of this study was to establish the moderating influence of organization culture in the relationship between workforce diversity and employee performance in public universities in Western Kenya. The study was guided by positivism research philosophy, descriptive survey research design and correlational research design. The target population included the chairpersons of departments of the public universities in Western Kenya, this comprised 120 people. A census of all the head of departments was conducted and primary data was collected using questionnaires. A questionnaire was used collect the primary data while data abstraction form was used to collect secondary data university records and relevant publications in refereed journals. Data was analyzed using descriptive and inferential statistics; frequencies, percentage, mean, standards deviation, Pearson's correlation, hypothesis testing and multiple linear regression analysis were adopted. The questionnaire return rate was $78 \%$. Correlation and regression
\end{abstract}


analysis established a statistically significant positive relationship between workforce diversity variables and employee performance. Hypothesis testing established that organization culture significantly moderates the relationship between workforce diversity and employee performance in public universities in Western Kenya with critical value $=2.48$ and $F(36,56)=12.543,2.48<12.543$. It was concluded that organization culture is a critical component in moderating the relationship between workforce diversity and employee performance. Further, age diversity, gender diversity, ethnic diversity and education background diversity influence employee performance positively and majority of the employees are positive about workforce diversity practices in public universities in Western Kenya. The study recommended that the management should continue to uphold its workforce diversity policies and practices in order to increase the benefits of workforce diversity.

Keywords: Organization Culture, Workforce Diversity, Employee Performance, Human Resource Management

\section{Background of the Study Organization Culture}

Organizational culture is the set of shared values, beliefs, and norms that influence the way employees think, feel, and behave in the workplace (Schein, 2011). Culture is transmitted to an organization's members by means of socialization and training, rites and rituals, communication networks, and symbols. Organizational culture has four functions: gives members a sense of identity, increases their commitment, reinforces organizational values, and serves as a control mechanism for shaping behavior (Nelson and Quick, 2011). Culture can affect technology transfer, managerial attitudes, managerial ideology and even government-business relationships. The cultural variations in organization can vary from being rather similar to completely unlike. To manage effectively in a global or a domestic multicultural environment, we need to recognize the differences and learn to use them to our advantage, rather than either attempting to ignore differences or simply allowing differences to cause problems (Adler, 1997). Different models of organizational culture exist in literature. Famous among these models are Schein (1992) Kotter and Heskett (1992) Hofstede, Neuijen, Ohayv and Sanders (1990) Cameron and Quinn (1999) and Denison (1990).

Cox (2001) defines workforce diversity as the variation of social and cultural identities among people existing together in a defined employment or marketing setting. William and O'Reilly (1998) also defines workforce diversity as the degree of heterogeneity among team members on specified demographic dimensions, their theory aiming to explain how such heterogeneity affects team processes and performance. Thomas and Ely (1996) explains that workforce diversity should be understood as the varied perspectives and approaches to work, that members of different identity groups bring. They add that it refers to the co-existence of employees from various social-cultural backgrounds within the company. Workforce diversity therefore requires a type of organizational culture in which each employee can pursue his or her career aspirations without being inhibited by age, gender, race, nationality, religion, physical ability or other factors that are irrelevant to performance (Bryan, 1999). Employee diversity is therefore a concept that recognizes the benefits to be gained from differences. It differs from equal opportunity, which aims to legislate against discrimination, and it assumes that people should be assimilated into the organization, and often relies on affirmative action. 
Thus, managing diversity means understanding its effects and implementing behaviors, work practices and policies that respond to them in an effective way (Cox, 2001).

\section{Dimensions of Diversity}

Diversity is distinguished along the primary, secondary and tertiary or organizational dimensions. Differences among employees can be categorized into two aspects; primary differences such as; age, gender, race etc. and the secondary differences such as; educational background, communication style, etc. (Aydan, 2016). Primary dimension reveals the key dissimilarities among diverse individuals as well as the highest impact on initial encounters, it could be quickly detected, and it also serve as a filter through which people view the world. It includes visible identity characteristics such as; age, gender, sexual orientation, physical abilities, ethnicity, race, etc. (Sayers, 2012). Powell (2011) adds that they are those essential unchangeable personal characteristics that exert significant lifelong impacts and they shape our basic self-image sense of identity. Secondary differences include; educational background, communication style, marital status, organizational role and position, religion, geographic location, income, work experience and work style, are qualities that are not noticeable in the first encounter and can even change throughout different encounters. These dimensions appear to be less visible, exert a more variable influence on personal, and add a more subtle richness to the primary dimension of diversity (Sayers, 2012). People are usually less sensitive about these aspects because they are element, we have made a choice on and we have the power to change them. The secondary dimensions of diversity are referred to by organizational researchers as experience-based diversity. This form of diversity includes a wide range of differences that are acquired, discarded, and/or modified throughout one's lifetime and as a result, are less pertinent to one's core identity. Powell (2011) said the secondary dimensions are our personal changeable characteristics. Characteristics that over the years we have acquired, we may decide to modify or even abandon throughout our lifetime. Organizational dimension deal with characteristics within the organization such as; organizational structure, part time or full time, organizational climate or culture, status, etc. (Sayers, 2012). The basis for secondary and organizational dimensions of diversity is information processing and decision-making theory. This perspective suggests that diversity when managed will have positive implications on work group outcomes since such groups will have a wide array of views, skills, and information. Educational background, functional and industrial experience are part of the competencies that one employs when undertaking a task. The ability to productively discuss and examine task related content issues grounded in a diverse set of perspectives can enhance performance.

\section{Employee Performance}

Durga (2017) defined performance as the act of executing a task or an accomplishment or achievement. He adds that employee performance is how well an employee is effectively fulfilling his/ her job requirement or discharging his/ her duties so as to achieve good results. O'Flynn, et al. (2001) citing William and O'Reilly (1998) said employee performance is defined using three criteria. First criteria is that employees' output meets the standard of performance set by the organization's external customers. Secondly, employee performance can be defined in terms of how the social processes utilized in the performance of their jobs enhances or maintain the capability of the employees to work together on subsequent group tasks. Finally, that employee's personal needs are satisfied instead of them being frustrated 
by the group performance. O'Flynn, et al. (2001) citing Ancona (1992) argue that there are multiple dimensions when it comes to rating of performance seeing that different constituents have their different performance criteria and access to data. For instance, management may be more interested in looking at the output of the employees whereas; the employees make be interested in creating a productive environment for themselves. Information and decision making theory predict that a positive outcome exist between employee performance in intellectual and complex tasks and information as employees have diverse knowledge, skills, experience and expertise which results in innovation, new product design and improved decision making.

\section{Statement of the Problem}

Higher education world over is undergoing rapid transformation in the face of changing global dynamics. In Kenya, these transformations have seen rapid expansion of public universities in the recent past. Universities are established to meet specific objectives in order to justify huge public expenditure on them. Today Kenya Government is pursuing vision 2030- a new development blueprint which aims to transform Kenya into a middle-income country (Government of Kenya, 2007). Critical players in achieving this are the universities, because education and training at university create sustainable workforce in form of human resource capital for national growth and development and a national research base at various sectors of economy which are necessary in modern industrial and technological world. Therefore, the performance of universities is instrumental in Kenya's overall economic growth and development.

However, to achieve these objectives, universities must adopt and implement various best human resource management practices. Research has shown a positive relationship between workforce diversity and performance (Kundu, 2001; Otike, 2009), but implementation of these practices is influenced by the culture of a particular organization. This study therefore investigates the moderating influence in the relationship between workforce diversity and employee performance in public universities in Western Kenya given that we have limited studies on this in Kenya.

\section{Objective of the Study}

The objective of this study was to establish the moderating influence of organization culture in the relationship between workforce diversity and employee performance in public universities in Western Kenya.

\section{Hypothesis of the Study}

The null hypothesis $\left(\mathrm{H}_{0}\right)$ of the study was; organizational culture does not have a statistically significant moderating influence in the relationship between workforce diversity and employee performance in public universities in Western Kenya.

\section{Literature Review}

Kotter and Heskett (1992) suggest that there is a positive link between culture and performance. Moreover, Denison and Mishra (1995) have contributed significantly to the field of culture and performance studies whereby culture has been treated as variable for a specific research purpose. For example, in their study, utilizing a more rigorous methodological approach, discovered that cultural strength was significantly correlated with short-term financial performance. Schneider (1990) also found that organizations that focus clearly on 
the culture are more successful. It is because focused cultures provide better financial returns (which include higher return on investment, higher return on assets and higher return on equity). The findings of a study on the relationship between organization culture and performance by Gordon and Christensen (1993) have also reported that industry moderates the link between organization culture and performance. These findings have advanced understanding of the determinants and performance effects of corporate culture. However, Chow, Kato and Merchant (1996) observe that, there are some aspects of organization culture that may enhance performance in one national setting, but they may not be effective, and may in fact be dysfunctional, in another. This implies that corporate cultures are not universal. Previous research on workforce diversity suggests that diversity can be either detrimental or beneficial for employee performance. For instance, employee diversity is positively associated with creativity and problem-solving skills and negatively related with cohesiveness and cooperation (Erasmus, 2007). Good work force diversity practices in the area of human resources are believed to enhance both employee and organizational performance. Furthermore, employee diversity allows increased creativity, a wider range of perspectives, better problem definition, more alternatives and better solutions. It is also argued that with decreasing homogeneity in the workforce, it has become crucial for organizations to develop equal opportunities and diversity management policies to maintain the skills of employees with diverse backgrounds in order to protect their competitive position in the marketplace (Kochan et al., 2003).

Ellis and Sonnenfield (1994) argue that there is a relationship between a positive diversity climate, job satisfaction, and commitment to the organization. Proper diversity management can increase an employee's self-esteem and feeling of no belongingness to the organization especially, if the employee is from a minority group. Although an increasing number of organizations are attempting to enhance inclusiveness of underrepresented individuals through proactive efforts to manage their diversity, they may only gain from diversity through proper management and adjustment. To effectively manage diversity, an organization must value diversity; it must have diversity, and it must change the organization to accommodate diversity and make it an integral part of the organization (Gilbert, Stead and Ivancevich, 1999). Good workforce diversity practices in the area of human resources are believed to enhance employee and organizational performance (Hall and Parker, 1993). Diversity brings the value of different employee perspectives and varied types of contribution especially when organizational members increasingly reflect the diverse custom base of the organization. This provides a way in which organizations can understand, and therefore meet, their customer needs.

In addition, Carrel (2006) proposes that for an organization to succeed, its strategies must consist of managing change, establishment of appropriate diversity management policies and procedures and target diversity related competencies. The desired outcomes of diversity include attracting and developing the best employees which should give the organization a competitive edge to generate greater profits that support job security. Carrel goes further notes that due to the fact that employees can understand how these outcomes are desirable, they will support the organization's efforts at managing diversity and embrace a culture that supports diversity. 


\section{Theoretical Framework}

Diversity theorists have recently turned to the well-established field of social psychology for insights into how diversity affects individuals and groups in organizations. Social psychologists have examined the processes involved with social identity and intergroup relations and diversity scholars recognized that this research tradition can provide a solid background for emerging theories on workplace diversity. Organizational researchers often refer to inborn human characteristics as dimensions of diversity, or social category diversity. The theoretical foundations for primary dimensions of diversity include the self-categorization theory (Turner, 1982), the social identity theory (Tajfel, 1978), the similarity paradigm theory (Thatcher, 1999), and the racial identity theory (Jehn, 1999). These theories describe how people react to observable demographic characteristics. The primary dimensions of diversity shape people's perception and behavior without regard to work-task relevance. According to O'Flynn, Ricciotti, Nicholas, Lau, Sammaritino and Fisher (2001) the three most commonly used theories of diversity are the social categorization theory, the similarity attraction paradigm and the informational diversity and decision-making perspective (Simon, 1947). The other theories used in this study are the theory of organization culture and effectiveness (Denison and Mishra, 1995) and behavior engineering model (Gilbert, 1978).

The objective this study, to establish the moderating influence of organization culture on the relationship between workforce diversity and employee performance in public universities in Western Kenya was based on the Denison Organizational Culture Survey. Denison and Neale (2000) isolated four measurable variables that was adopted in this research which include employee Involvement and participation that results in a sense of ownership and responsibility leading to commitment. Consistency is the second variable and is seen when organizational culture comprising of shared values, beliefs and symbols becomes internalized, then consensus and coordination are more effectively achieved. Adaptability which is based on the need for the organization to recognize changes in the external and internal environment and then make the appropriate responses to accommodate those changes. Finally, broadly shared Mission helps the organization find purpose, meaning and direction.

\section{Research Methodology}

Descriptive survey research design and correlational research design were adopted for this study. Descriptive research studies are studies which are concerned with quantitatively describing the characteristics of a particular individual or characteristics of a group (Kothari, 2009). Correlational design established the existence of a relationship or interdependence between two or more aspects of the variables. The study was guided by a positivism research paradigm. The target population of the study was public universities in Western Kenya region: Masinde Muliro University of Science and Technology, Maseno University, Jaramogi Oginga Odinga University of Science and Technology and Kisii University, from which the findings were later generalized. The study took a census of all the chairpersons of departments of the public universities in Western Kenya, this was coming to a total of 120 people. By their very nature, public Universities in Western Kenya region share similar contextual backgrounds with their counterparts in other parts of Kenya. They enjoy same policy regime from the Republic of Kenya; are financed and facilitated by the same government. A questionnaire was used to collect the primary data while data abstraction form was used to collect secondary data university records and relevant publications in refereed journals. The questionnaire was piloted on 12 respondents, Cronbach's alpha coefficient was used to test the reliability of the 
questionnaire. Content validity enhanced through expert review by the supervisors and field practitioners, their ratings were used to compute the content validity index. Data was analyzed using descriptive and inferential statistics. In particular, frequencies, percentage, mean, standards deviation, Pearson's correlation, hypothesis testing and multiple linear regression analysis were adopted. The findings were presented in Tables.

\section{Findings and Discussions}

\section{Questionnaire Return Rate}

The respondents who filled and returned usable questionnaires were 93, out of the targeted 120 giving a return rate of $78 \%$. The $22 \%$ of the respondents failed to fill the questionnaires even after several follow up. According to Mugenda and Mugenda (2003), a return rate of $50 \%$ is adequate for analysis and reporting; a rate of $60 \%$ is good and a return rate of $70 \%$ and over is excellent. This meant that the return rate of $78 \%$ was excellent and therefore enough for the study to proceed to the data analysis, presentation, interpretation and discussion.

\section{Reliability Test Results}

The Cronbach's alpha for the variable was established as 0.939. Hair, Black, Babin, Anderson, and Tatham (2006) indicate 0.7 to be the minimum acceptable reliability coefficient. Since, the alpha coefficients for all the variables were greater than 0.7 , a conclusion was drawn that the instrument had an acceptable reliability coefficient and was appropriate for the study to proceed.

\section{Validity Test Results}

Validity was determined by use of the Content Validity Index (CVI). CVI was obtained by adding up the items rated 3 and 4 and dividing this sum by the total number of items in the questionnaire. A CVI of 0.747 was obtained. Oso and Onen (2009), state that a validity coefficient of at least 0.70 is acceptable as a valid research instrument hence the adoption of the instrument for the study.

\section{Normality Test}

Kolmogorov-Smirnov test was done to test the normality of all the variables. The results are shown in the Table 1.

Table 1: Kolmogorov-Smirnov Test

\begin{tabular}{lrcc}
\hline & \multicolumn{3}{c}{ Kolmogorov- Smirnov } \\
& Statistic & Df & Sig \\
\hline Age Diversity & 0.176 & 93 & 0.000 \\
Gender Diversity & 0.192 & 93 & 0.000 \\
Ethnic Diversity & 0.168 & 93 & 0.000 \\
Education Background & 0.115 & 93 & 0.004 \\
Diversity & & & \\
Employee Performance & 0.203 & 93 & 0.000 \\
\hline
\end{tabular}

The Kolmogorov- Smirnov test showed that the data was normally distributed in all the study variables, the $p$-values are $<0.05, C L=95 \%$. The $Q-Q$ plot normality tests showed that the data 
on all the variables: Age Diversity, Gender Diversity, Ethnic Diversity, Education Background diversity and Employee Performance were normally distributed.

Independent Errors Test

The Durbin- Watson statistic was used for test independent error test and results are shown in Table 2.

Table 2: Independent Errors Test

Std. Error of the Estimate Durbin-Watson

$\begin{array}{ll}3.82141 & 1.717\end{array}$

The Durbin-Watson value is $=1.617<2$, indicated that the residuals are not correlated and therefore the data met the conditions for linear regression analysis.

\section{Collinearity Statistics}

Table 3: Collinearity Statistics

\begin{tabular}{lcr} 
Model & \multicolumn{2}{c}{ Collinearity Statistics } \\
& Tolerance & VIF \\
\hline Age Diversity & 0.429 & 2.330 \\
Gender Diversity & 0.454 & 2.202 \\
Ethnic Diversity & 0.823 & 1.214 \\
Education Background & & \\
Diversity & 0.500 & 2.000 \\
\hline
\end{tabular}

a. Dependent Variable: Employee Performance

The analysis of tolerance and VIF values showed that there was no problem of multicollinearity, all the tolerance values were $<1$ while the VIF values were $<10$.

\section{Descriptive Statistics on Organization Culture in Public Universities in Western Kenya}

The respondents were asked to give their opinion on the level of agreement or disagreement using Likert scale statements of 1-5 where, 1 = strongly disagree, 2= disagree, 3=neutral, 4=agree, $5=$ strongly agree. The frequencies and percentages, mean (M) and standard deviation (SD) were computed and shown in Table 4. 
Table 4: Organization Culture in Public Universities in Western Kenya

\begin{tabular}{|c|c|c|c|c|c|c|c|}
\hline Statement & SD & D & $\mathbf{N}$ & A & SA & M & SD \\
\hline $\begin{array}{l}\text { The belief in capability } \\
\text { development } \\
\text { employees }\end{array}$ & $0(00)$ & $9(9.7)$ & $19(20.4)$ & $34(36.6)$ & $31(33.3)$ & 3.94 & 0.96 \\
\hline $\begin{array}{l}\text { The culture of team } \\
\text { orientation }\end{array}$ & $0(00)$ & $2(2.2)$ & $20(21.5)$ & $41(44.1)$ & $30(32.3)$ & 4.06 & 0.79 \\
\hline $\begin{array}{l}\text { The culture of employee } \\
\text { empowerment }\end{array}$ & $2(2.2)$ & $11(11.8)$ & $7(7.5)$ & $39(41.9)$ & $34(36.6)$ & 3.99 & 1.05 \\
\hline $\begin{array}{l}\text { The tradition of } \\
\text { accommodating diverse } \\
\text { opinion }\end{array}$ & $0(00)$ & $7(7.5)$ & $29(31.2)$ & $28(30.1)$ & $29(31.2)$ & 3.85 & 0.95 \\
\hline $\begin{array}{lr}\text { The culture } & \text { of } \\
\text { coordination } & \text { and } \\
\text { integration } & \text { among } \\
\text { employees } & \end{array}$ & $2(2.2)$ & $3(3.2)$ & $19(20.4)$ & 35 & $34(3$ & 4.03 & 0.95 \\
\hline $\begin{array}{l}\text { The culture of creating } \\
\text { positive change }\end{array}$ & $2(2$ & $12(12.9)$ & $14(15.1)$ & $37(39.8)$ & $28(3$ & 3.83 & 1.07 \\
\hline $\begin{array}{l}\text { The culture of customer } \\
\text { focus in operations }\end{array}$ & $0(00)$ & $5(5.4)$ & $25(26.9)$ & $28(30.1)$ & $35(37.6)$ & 4.00 & 0.93 \\
\hline $\begin{array}{l}\text { The tradition of } \\
\text { organization learning }\end{array}$ & $0(00)$ & $10(10.8)$ & $17(18.3)$ & $46(49.5)$ & $20(21.5)$ & 3.82 & 0.89 \\
\hline The culture of focusing & $0(00)$ & $5(5.4)$ & $19(20.4)$ & $45(4$ & $24(2$ & 3.95 & 0.82 \\
\hline $\begin{array}{l}\text { The belief in strategic } \\
\text { direction and intent }\end{array}$ & $0(00)$ & $5(5.4)$ & $18(19.4)$ & $41(44.1)$ & $29(31.2)$ & 4.01 & 0.85 \\
\hline $\begin{array}{l}\text { The tradition of } \\
\text { commitment } \\
\text { organization's goals and } \\
\text { objectives }\end{array}$ & $0(00)$ & $6(6.5)$ & $16(17.2)$ & $40(43.0)$ & $31(33.3)$ & 4.03 & 0.88 \\
\hline Composite mean & & & & & & 3.96 & \\
\hline
\end{tabular}

The study established that organization culture is a critical consideration in achieving employee performance in public universities in Western Kenya. The results show that to a large extent organization culture practices are practiced in public universities in Western Kenya with a composite mean of 3.96. In relation to respective indicators, the study show that 'Involvement' and 'Mission' traits had the highest means of 3.99 each, while 'Adaptability' had the lowest mean of 3.88 . 
Correlation Analysis of Workforce Diversity moderated by Organization Culture, and Employee Performance in Public Universities in Western Kenya

Table 5: Correlation between Moderated Workforce Diversity and Employee Performance

\begin{tabular}{llrr}
\hline Variables & & \multicolumn{1}{c}{$\begin{array}{c}\text { Moderated Workforce } \\
\text { Diversity }\end{array}$} & $\begin{array}{c}\text { Employee } \\
\text { Performance }\end{array}$ \\
\hline Moderated Workforce & Pearson & 1 & $0.585^{* *}$ \\
Diversity & Sig. (2-tailed) & & 0.000 \\
& $\mathrm{~N}$ & 93 & 93 \\
Employee & Pearson & $0.585^{* *}$ & 1 \\
Performance & Correlation & & \\
& Sig. (2-tailed) & 0.000 & 93 \\
\hline
\end{tabular}

**. Correlation is significant at the 0.01 level (2-tailed).

A correlation analysis between workforce diversity and employee performance revealed that there is a statistically significant moderate positive association between workforce diversity and employee performance in public universities in Western Kenya, $r=0.456, p<0.001$, Confidence Level $=95 \%$ (2-tailed). As shown in table 5 , there is a statistically significant moderate positive association between workforce diversity, moderated by organizational culture and employee performance in public universities in Western Kenya, $r=0.585, p<0.001$, Confidence Level $=95 \%$ (2-tailed).This means that when workforce diversity and organizational culture improves, then employee performance also improves in public universities in Western Kenya. The results are in agreement with the findings of Gordon and Christensen (1993) study on the relationship between corporate culture and performance, a comparative study of Taiwanese and US manufacturing firms. The research reported that industry moderates the link between corporate culture and performance. These findings have advanced understanding of the determinants and performance effects of organization culture. However, Chow, Kato and Merchant (1996) study on the use of organizational controls and their effects on data manipulation and management myopia, a comparison between Japan and the US, observe that, there are some aspects of corporate culture that may enhance performance in one national setting, but they may not be effective, and may in fact be dysfunctional, in another. This implies that organization cultures are not universal.

\section{Hypothesis Testing}

$\mathrm{H}_{0}$. Organizational culture does not have a statistically significant moderating influence in the relationship between workforce diversity and employee performance in public universities in Western Kenya. The results are shown in table 6 
Table 6: Hypothesis Testing

ANOVA

Sum of Squares Df $\quad$ Mean Square $\quad F$

Sig.

\begin{tabular}{llll} 
Between Groups & 1560.306 & 36 & 43.342 \\
$12.543 \quad 0.000$ & & & \\
Within Groups & 193.500 & 56 & 3.4555 \\
Total & 1753.806 & 92 & \\
\hline
\end{tabular}

The study tested the null hypothesis $\left(\mathrm{H}_{0}\right)$ that organizational culture does not have a statistically significant moderating influence in the relationship between workforce diversity and employee performance in public universities in Western Kenya. The $\mathrm{F}$ distribution table gave a reading of critical value $=2.48$ and $F(36,56)=12.543,2.48<12.543$, because the calculated value is greater than the critical value, therefore we reject the null hypothesis, this means that it is statistically very unlikely that the null hypothesis $\left(\mathrm{H}_{0}\right)$ is true. We revert to the alternative hypothesis $\left(\mathrm{H}_{1}\right)$ that organizational culture has a significant moderating influence in the relationship between workforce diversity and employee performance in public universities in Western Kenya. The results are consistence with Emmanuel and Lloyd (2000) study which examined the nature of relationship between leadership and performance and organization culture and performance from United Kingdom companies and presented empirical evidence which suggested that the relationship between leadership style and performance is mediated by the form of organizational culture that is present. The results of this study indicated that leadership style is not directly linked to performance but is merely indirectly associated with organization culture being a moderating variable. In contrast, competitive and innovative cultural traits were directly linked with performance. The findings suggest that organizational culture has a significant moderating influence on the relationship between workforce diversity and employee performance in public universities in Western Kenya.

\section{Multiple Linear Regression Analysis for Moderated Performance Model}

The analysis of the significance tests of the overall regression model was carried with the moderating variable. This was to establish the effect of the moderating variable on the independent variables' contribution to the dependent variable- employee performance. The findings are presented in Table 7.

Table 7: Multiple Linear Regression Analysis for Moderated Performance Model

\begin{tabular}{|c|c|c|c|c|c|c|}
\hline \multirow[t]{2}{*}{ Model } & \multicolumn{2}{|c|}{$\begin{array}{l}\text { Unstandardized } \\
\text { Coefficients }\end{array}$} & \multirow[t]{2}{*}{$\mathbf{T}$} & \multirow[t]{2}{*}{ Sig. } & \multicolumn{2}{|c|}{ 95.0\% Confidence Interval for B } \\
\hline & B & Std. Error & & & $\begin{array}{l}\text { Lower } \\
\text { Bound }\end{array}$ & Upper Bound \\
\hline (Constant) & -2.703 & 2.728 & -0.991 & 0.324 & -8.123 & 2.717 \\
\hline Workforce Diversity & 0.057 & 0.027 & 2.103 & 0.038 & 0.003 & 0.110 \\
\hline Organizational Culture & 0.254 & 0.044 & 5.780 & 0.000 & 0.166 & 0.341 \\
\hline Moderator Effect & 0.924 & 0.272 & 3.397 & 0.001 & 0.383 & 1.464 \\
\hline
\end{tabular}

a. Dependent Variable: Employee Performance 
The statistical model was as follows:

$\mathbf{Y}=-2.703+0.057 \mathrm{X}+0.254 \mathrm{Z}+0.924 \mathrm{X}_{2}+3.071$

A multiple linear analysis was carried out by introducing the moderating variable organization culture and the findings show that organizational culture significantly moderates the relationship between workforce diversity and employee performance, $(p=0.001)$, the moderation effect is positive $(\beta=0.254)$, this means that organizational culture enhances employee performance. The results corroborate with Emmanuel and Lloyd (2000) study on the nature of relationship between leadership and performance and organization culture and performance in United Kingdom companies. The study results found out that leadership style is not directly linked to performance but is merely indirectly associated because of the moderation of the competitive and innovative organization culture. Further, Shahzad, Zahid, and Gulzar (2013) study analyzed the overall impact of organizational culture directly or indirectly on employee's job performance in software houses in Pakistan. The study found out that organizational culture has a significant positive impact on the performance of employee's job.

\section{Model Summary}

Table 8: Model Summary

Model Summary

Model R R Square Adjusted R Square $\begin{gathered}\text { Std. Error of the } \\ \text { Estimate }\end{gathered}$

\begin{tabular}{lllll}
\cline { 2 - 3 } & $0.839^{\mathrm{a}}$ & 0.704 & 0.698 & 3.82141
\end{tabular}

a. Predictors: (Constant), Age Diversity, Gender Diversity, Ethnic Diversity and Education Background Diversity, b. Dependent Variable: Employee Performance

The $\mathrm{R}$ value is the correlation coefficient between the dependent variable and the independent variables. According to the Model Summary, the value of correlation coefficient(R) of four independent variables (age diversity, gender diversity, ethnic diversity and education background diversity) with the dependent variable (employee performance) is 0.839. Therefore, there is positive and high correlation between four independent variable and dependent variable. Besides that, Model Summary also indicates the coefficient of determination ( $R$ square). The findings showed that the independent variables: age diversity, gender diversity, ethnic diversity and education background diversity explained $70.4 \%$ $\left(R^{2}=0.704\right)$ of the variance in the dependent variable, employee performance. However, it still leaves 29.6 (100\% - 70.4\%) unexplained in this research. In other words, there are other additional variables that are important in explaining employee performance that have not been considered in this research.

\section{Conclusion}

The conclusion is that organization culture has a moderating influence on the relationship between workforce diversity and employee performance based on the regression, correlation and hypothesis testing models. The study indicate that organizational culture has a statistically significant moderating influence on the relationship between workforce diversity 
and employee performance in public universities in Western Kenya. Majority of the employees are positive about organization culture practices in public universities and 'Involvement' and 'Mission' are the most popular cultural traits.

\section{Recommendations}

In view of the stated findings and conclusions, the study recommends that public universities should strive to enhance the 'Adaptability' traits which are based on the need for the organization to recognize changes in the external and internal environment and then make the appropriate responses to accommodate those changes.

\section{References}

Ancona, D. G., and Caldwell, D. F. (1992). Demography and design: Predictors of new product team performance. Organization Science, 3:321-341.

Aydan, O. (2016). The Effect of Diversity Management on Job Satisfaction and Individual Performance of Teachers. Educational Research and Reviews, 11(3), 105-112.

Bryan, J. H. (1999). The Diversity Imperative. New Delhi: Executive Excellence.

Cameron, K. and Quinn, R. (1999). Diagnosing and changing organizational culture: Based on the competing values framework, Addison-Wesley, Reading, MA.

Carrel, M. R. (2006). Defining Workforce Diversity Programs and Practices in Organizations: A Longitudinal Study. Labor Law Journal. Spring, 2006.

Chow, C. W., Kato, Y. and Merchant, K. A. (1996). The use of organizational controls and their effects on data manipulation and management myopia: A Japan vs. U.S. comparison. Accounting, Organizations and Society 21(2-3): 175-192.

Cox, T. (2001). Creating the Multicultural Organization: A Strategy for Capturing the Power of Diversity, San Francisco: Jossey-Bass.

Denison, D. R. (1990). Corporate culture and organizational effectiveness. New York: John Wiley.

Denison, D. R., \& Mishra, A. K. (1995). Toward a theory of organizational culture and effectiveness. Organization Science, 6, 204-23.

Denison, D. R., \& Neale, W. (2000). Denison Organizational Culture Survey. MI: Aviat.

Ellis, C., Sonnenfield, J. A. (1993). Diverse Approaches to Managing Diversity. Human Resource Management Journal, Vol. 33 No.1. Emerald Publications.

Emmanuel, O. \& Lloyd, C. H. (2000). Leadership style, organizational culture and performance: empirical evidence from UK companies international. Journal of Human Resource Management, 11:4, 766-788.

Erasmus, L. (2007). The Management of Workforce Diversity and the Implications for Leadership at Financial Asset Services. Business Management, University of Johannesburg.

Gilbert, J. A., Stead, B. A., and Ivancevich, J. M. (1999). 'Diversity Management: A New Paradigm'. Journal of Business Ethics. No 21. Netherlands: Kinutt Academic Publishers.

Gilbert, T. F. (1978). Human Competence: Engineering worthy Performance. New York: McGraw-Hill.

Gordon, G. G. \& Christensen, E. (1993). Industry Influences on the relationship between Management Culture and Performance: Paper presented at the national Meeting of the Academy of Management. Atlanta, GA. 
Government of Kenya. (2007). Vision 2030, Ministry of planning and National Development and the National Economic and Social Council (NESC), Office of the President.

Hair, J., Black, W., Babin, B., Anderson, R., \& Tatham, R. (2006). Multivariate data analysis (6th edition). Upper saddle River, N.J.: Pearson Prentice Hall.

Hall, D. T., Parker, A. P. (1993). The role of workplace flexibility in managing diversity. Organizational Dynamics Journal. Vol. 22, No.1.

Hofstede, G., Neuijen, B., Ohayv, D. \& Sanders, G. (1990). Measuring organizational cultures: a qualitative and quantitative study across twenty cases, Administrative Science Quarterly, 35, 285-316.

Jehn, K. A. (1999). Diversity, Conflict, and Team Performance: Summary of Program of Research. Performance Improvement Quarterly, 12(1), 6-19.

Kochan, T., Bezrukova, K., Ely, R., Jackson, S., Joshi, A., Jehn, K., Leonard, J., Levine, D., \& Thomas, D. (2003). The effects of diversity on business performance: Report of the diversity research network. Human Resource Management. 42. 3-21. 10.1002/hrm.10061.

Kothari, C. R. (2009). Research Methodology: Methods and Techniques. New Delhi. New Age International Publishers.

Kotter, J. P. \& Heskett, J. L. (1992). Corporate culture and performance. New York: Macmillan.

Kundu, S. C. (2001). Valuing Cultural Diversity; A study of employee reactions to employer efforts to value diversity in India. Proceedings of the $7^{\text {th }}$ Asia- Pacific Management Conference- The Great Asia in the $21^{\text {st }}$ century, University of Malaya, Kuala Lumpur, Malaysia and National Cheng Kung University, Tainan, ROC (2) pp. 635-646.

Mugenda, O. M. \& Mugenda, A. G. (2003). Research Quantitative and Qualitative Approaches. $2^{\text {nd }}$. Rev. Ed. Nairobi: Act press.

Nelson, D. L. \& Quick, J. C. (2011). Understanding Organizational behavior. Belmont, CA: Cengage South-Western.

O’Flynn, J., Ricciotti, A., Nicholas, S., Lau, K., Sammarino, A., Fisher, N. (2001). The theory of Diversity and Group Performance: Australian Centre for International business, 1-54.

Oso, W. Y., and Onen, D. (2009). A general guide to writing research proposal and report: A handbook of beginning researchers. Nairobi: Jomo Kenyatta Foundation.

Otike, F. W. (2009). Effects of workplace Diversity Management on organizational Effectiveness. European Journal of Business Management, 3 (21).

Powell, G. N. (2011). Women and Men in Management (4thEd.) Thousand Oaks: Sage Publications.

Sang, K. (2010). Outsourcing in Kenyan Universities. An Examination of Challenges and Opportunities. International Journal of Business and Social Science, 1, 204-212.

Sayers, J. (2012). Managing Diversity. Retrieved October 4, 2016, from www.bookboon.com/en/managing-diversity-ebook

Schein, E. H. (2011). Leadership and organizational culture. New York, NY: Wiley.

Schein, E.H. (1992). Organizational culture and leadership (2nd Ed.). San Francisco: JosseyBass Publishers.

Schneider, B. (1990). Organization Climate and Culture. San Francisco, Jossey-Bass Publishers. Sekaran, U. (2008). Research Methods for Business. A skill Building Approach., New York: John Willey \& Sons, Inc. 
Shahzad, F., Zahid, I. \& Gulzar, M. (2013). Impact of Organizational Culture on Employees Job Performance: An Empirical Study of Software Houses in Pakistan. Journal of Business Studies Quarterly; Vol. 5 Issue 2, p56.

Simon, H. A. (1947). Administrative Behavior: a Study of Decision-Making Processes in Administrative Organization (1st Ed.). New York: Macmillan.

Tajfel, H. (1978). The Achievement of Group Differentiation: differentiations Between Social Groups. London, England: Academic Press.

Thatcher, S. (1999). The Contextual Importance of Diversity: The Impact of Relational Demography and Team Diversity on Individual Performance and Satisfaction. Performance Improvement Quarterly, 12(1), 97-112.

Thomas, D. A., and Ely, R. D. (1996). Making Differences Matter: A New Paradigm for Managing Diversity. Harvard Business Review, Sept.-Oct.: 79-90.

Turner, J. C. (1982). Towards a Cognitive Redefinition of Social Group. Cambridge, England: Cambridge University Press.

Williams, K. Y. \& O’Reilly, C. A. (1998). Demography and Diversity in Organization: A Review of 40 years of Research. Research in Organization Behavior, 20, pg. 77-140. 